\title{
IMPACT ASSESSMENT OF ANTHROPOLOGICAL ACTIVITIES ON WATER QUALITY OF HISTORICAL GULAB SAGAR POND, JODHPUR, RAJASTHAN (INDIA)
}

\author{
Surendra Makwana \\ Research scholar \\ Department of Zoology, Jai Narain Vyas University \\ Jodhpur, Rajasthan(India)
}

\begin{abstract}
The present study was conducted to assess the water quality of Gulab Sagar pond at Jodhpur (Raj) during festive season, household activities \& domestic waste. Water samples were analyzed for physicochemical properties viz $\mathbf{p H}$, temperature, total alkalinity, total hardness, total calcium, DO, BOD, COD, and TDS.

This water body is situated inside the main city of Jodhpur and has been recently identified as a tourist spot. It was noted that the value of most of parameter significantly changed after the immersion period. Present study indicated that the tourist spot and historic pond was polluted due to religious activities of Ganesh Chaturthi \& Durga pooja festival and cause adverse effect on the aquatic ecosystem. We cannot stop these religious activities but public participation and awareness programs can reduce pollution. Generating awareness among the people and society about reducing pollution due to festival waste will help in conserving the ecosystem of these water bodies.
\end{abstract}

Keywords- Gulab Sagar, BOD, DO, water pollution, religious activity

\section{INTRODUCTION}

Water is an essential component of all living organisms on the earth. Most of the water on this planet is stored in ocean and ice caps. Most of our demand for water is fulfilled by rainwater, which gets deposited on the surface of groundwater resources. Water is the most important component of our life.
We cannot live without water. Any chemical or biological variation from normal composition leads to water pollution. Water of good quality is required for a living organism.

According to Reddy and Kumar, (2001) India is the country with a rich diversity of culture. People have deeply believed in rituals and follow their cultural activities. Several of the rituals are performed near water bodies. The Ganesh Chaturthi is one of the important festivals of Hindu and thousands of Ganesh idols of various sizes are immersed every year in different water bodies of the city.

In India idol immersion is another anthropogenic activity (Gupta, 2011). The idols of Lord Ganesh, Goddess Durga, etc. are worshipped with all rituals by Hindu are immersed in water bodies between September to October respectively every year.

According to Bajpai et al, $(2002,2009)$ water pollution occurs due to the city sewage and industrial waste discharge into the river in addition to many religious activities and now becomes a threat to the ecosystem. Ever growing religious activities and religious fanatics have now become a major threat to the ecosystem (Bajpai, 2003; Ujjain, 2011). Hence, there is an urgent need to develop the guidelines for idol immersion and enforce them in totality. Many social, religious, scientific and environmental dimensions are produced due to idol immersion Pollution.

Heritage water bodies are stagnant surface water bodies that receive and store freshwater received through rainfall. According to study of Mehta, (2013), these stagnant water bodies have a more complex and fragile ecosystem in comparison to running water bodies as they lack self-cleaning ability. This results 
in the ready accumulation of large quantities of toxic pollutants. More anthropogenic activities in and around these water bodies, damages the aquatic ecosystems and ultimately affects the overall physiochemical properties of water said by Upadhyay, (2010). Thousands of idols are immersed in Gulab Sagar pond, Kaylana Lake, and Baijika Talab, Umaid Sagar \&Takhat Sagar every year.

\section{Study Area}

Gulab Sagar Lake is historical pond sited about $6 \mathrm{~km}$ from Jodhpur city centre near Sardar Market. Gulab Sagar Lake is constructed by Gulab Rai (Mistress of Maharaja Vijay Singh) in 1788.

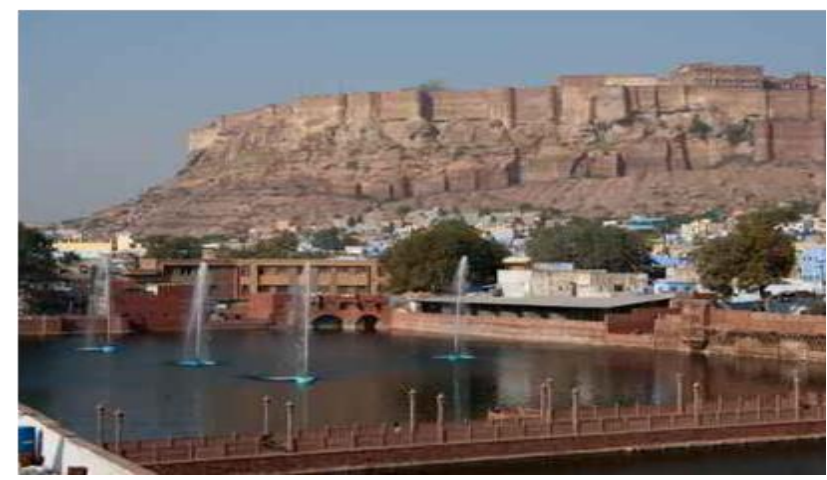

Figure1-Before anthropogenic activity view of historical pond

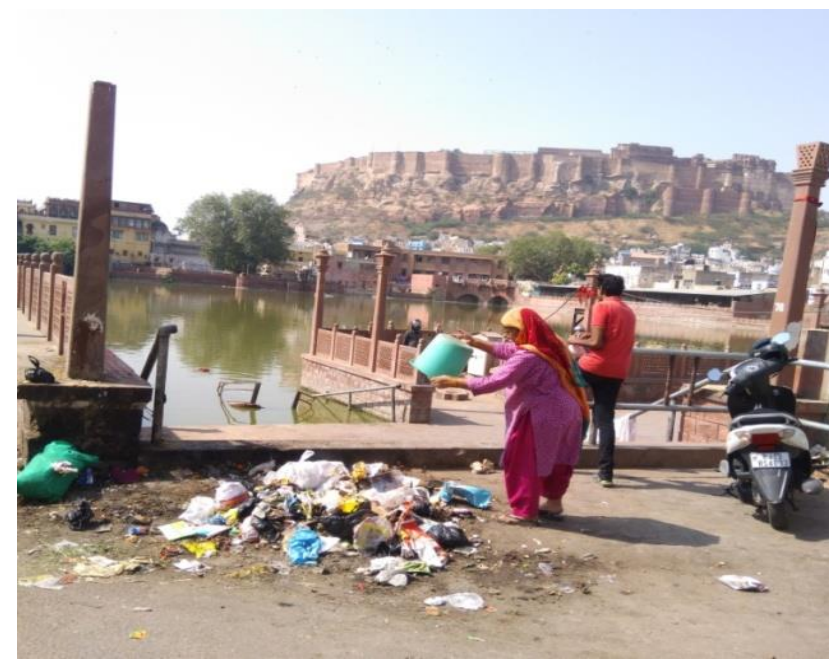

Figure 2- After anthropogenic activity, view of polluted pond

\section{RESULTS AND DISCUSSION}

Table 1. Different physicochemical parameter before during and after immersion

\begin{tabular}{|l|l|l|l|l|}
\hline S.No. & Parameter & Before & During & After \\
\hline
\end{tabular}

\section{Sampling Sites and Sample Collection}

The water samples were collected from the surface layer of immersion site of Gulab Sagar pond during morning hours. Pre-immersion samples were collected 3 days before immersion activities, immersion samples were collected during the immersion period and post-immersion samples were collected one week after the completion of Ganesh Visarjan. The collected samples were detected for various water quality parameters viz. $\mathrm{pH}$, TSS (Total suspended solids), TDS (Total dissolved solids), TS (Total Solids), Turbidity, Conductivity, hardness, Dissolved Oxygen (DO), Biological Oxygen Demand (BOD), and Chemical Oxygen Demand (COD). For analysis of the water samples, standard methods of Trivedi and Goyal, (1986) and APHA, (2005) were followed for the analysis. The temperature, $\mathrm{pH}$ analysis and fixation of dissolved oxygen were done at the site. 
International Journal of Engineering Applied Sciences and Technology, 2020

Vol. 4, Issue 10, ISSN No. 2455-2143, Pages 178-185

Published Online February 2020 in IJEAST (http://www.ijeast.com)

\begin{tabular}{|c|l|l|l|l|}
\hline & & immersion & immersion & immersion \\
\hline 1. & $\mathrm{pH}$ & 7.4 & 6.8 & 7.2 \\
\hline 2. & Temperature $\left({ }^{\circ} \mathrm{C}\right)$ & 33.5 & 31 & 31.5 \\
\hline 3. & $\begin{array}{l}\text { Total dissolved solids } \\
(\mathrm{mg} / \mathrm{l})\end{array}$ & 880 & 2325 & 1936 \\
\hline 4. & Total hardness $(\mathrm{mg} / \mathrm{l})$ & 224 & 265 & 254 \\
\hline 5. & Calcium $(\mathrm{mg} / \mathrm{l})$ & 23.20 & 30 & 28 \\
\hline 6. & Chloride $(\mathrm{mg} / \mathrm{l})$ & 19.00 & 470 & 345 \\
\hline 7. & Total alkalinity $(\mathrm{mg} / \mathrm{l})$ & 274 & 324 & 308 \\
\hline 8. & BOD $(\mathrm{mg} / \mathrm{l})$ & 5.31 & 8.65 & 3.70 \\
\hline 9. & COD $(\mathrm{mg} / \mathrm{l})$ & 32.14 & 40.50 & 48.51 \\
\hline 10. & Dissolved oxygen $(\mathrm{mg} / \mathrm{l})$ & 15.35 & 4.80 & 9.50 \\
\hline 11. & $\begin{array}{l}\text { Electrical conductivity } \\
(\mu \mathrm{S})\end{array}$ & 0.78 & 1.63 & 1.32 \\
\hline
\end{tabular}

pH -

$\mathrm{pH}$ of water found acidic 6.8 during the immersion period while it was 7.4 and 7.2 during the preimmersion and post-immersion period respectively. Acidity of water increases during immersion of idols. Variation in $\mathrm{pH}$ in collected water sample: Preimmersion, at immersion, and post-immersion for water samples collected from Gulab Sagar pond in Jodhpur is shown in Table.

\section{Temperature-}

The value of temperature during the pre-immersion, immersion and post-immersion period it was found 33.5, 31.0 and $31.5{ }^{\circ} \mathrm{C}$ respectively. This indicated temperature of water increases during immersion of idols.

\section{Total dissolved solids -}

Total dissolved solids were recorded remarkable high $2325 \mathrm{mg} / \mathrm{l}$ during the immersion period while preimmersion and post-immersion period, it was found $880 \mathrm{mg} / 1$ and $1936 \mathrm{mg} / 1$ respectively.

\section{Total alkalinity-}

In the present study total alkalinity was found 324 $\mathrm{mg} / 1$ during immersion period compare to pre immersion and post-immersion period $274 \mathrm{mg} / 1$ and $308 \mathrm{mg} / 1$ respectively.

\section{Total hardness -}

Total hardness was analysed as $265.0 \mathrm{mg} / \mathrm{l}$ during immersion period while $224 \mathrm{mg} / 1$ during preimmersion and $254 \mathrm{mg} / 1$ in post-immersion period.

\section{Calcium -}

The calcium hardness was observed as $30.00 \mathrm{mg} / 1$ during immersion period while $23.20 \mathrm{mg} / 1$ during pre
Immersion period and $28 \mathrm{mg} / 1$ during postimmersion period respectively.

\section{Dissolved Oxygen-}

During immersion period dissolved oxygen was observed very low $4.80 \mathrm{mg} / 1$ while it was observed comparably high during the pre-immersion 15.35 $\mathrm{mg} / 1$ and post-immersion $9.50 \mathrm{mg} / 1$.

Chloride -

The Chloride was observed as $470 \mathrm{mg} / 1$ during immersion period while $19 \mathrm{mg} / 1$ during pre immersion period and $345 \mathrm{mg} / 1$ during postimmersion period respectively.

\section{Biochemical Oxygen Demand-}

BOD was observed $8.65 \mathrm{mg} / \mathrm{l}$ during the immersion period that was significantly high compared to preimmersion $5.31 \mathrm{mg} / 1$ and $3.70 \mathrm{mg} / 1$ during postimmersion period.

\section{Chemical Oxygen Demand-}

High value of COD $40.50 \mathrm{mg} / 1$ was observed in the immersion period that was comparatively low 32.14 $\mathrm{mg} / 1$ during pre-immersion and $48.51 \mathrm{mg} / 1$ during post-immersion period.

\section{Electrical conductivity-}

Electrical conductivity was observed $1.63 \mathrm{~ms}$ during the immersion period that was significantly high compared to pre-immersion $0.78 \mathrm{~ms}$ and $1.32 \mathrm{~ms}$ during the post-immersion period.

There was no significant difference in $\mathrm{pH}$ and temperature during Ganesh visarjan. Changes in various parameters like electrical conductivity, TDS, total alkalinity, total hardness, calcium hardness, DO 
and COD etc. during immersion period have been reported in the present study and the results are supported by Dhote et al. ,(2001), Vyas et al. ,(2006, 2008) ,Khapekar \& Nandkumar ,(2009).

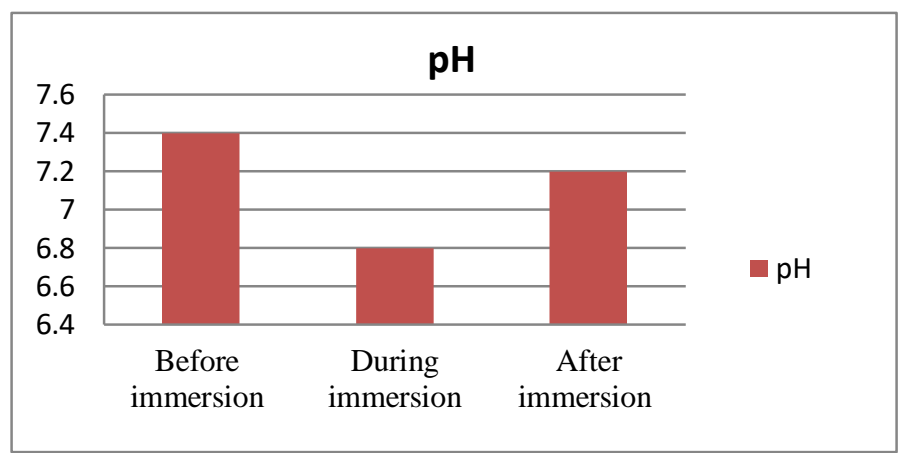

Figure 4 Comparison of $\mathrm{pH}$

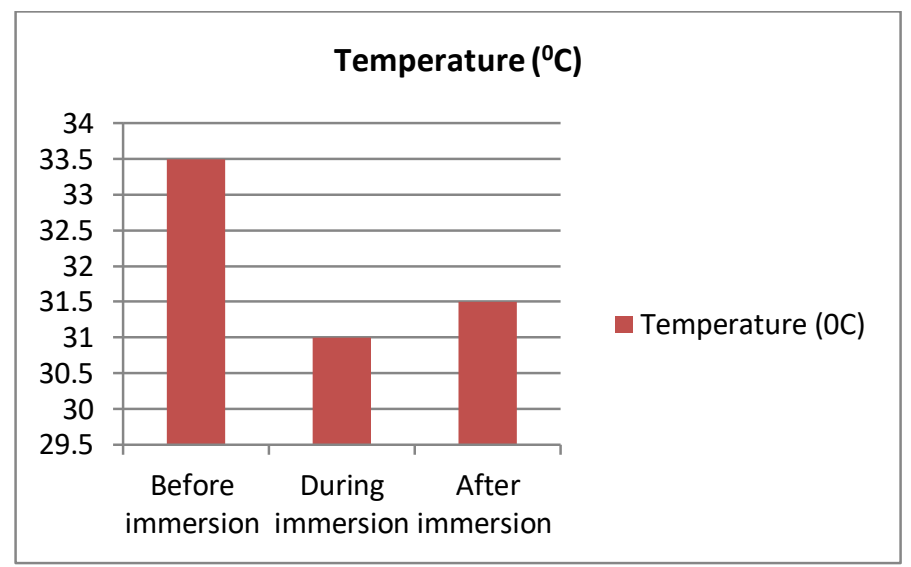

Figure 5 Comparison of Temperature

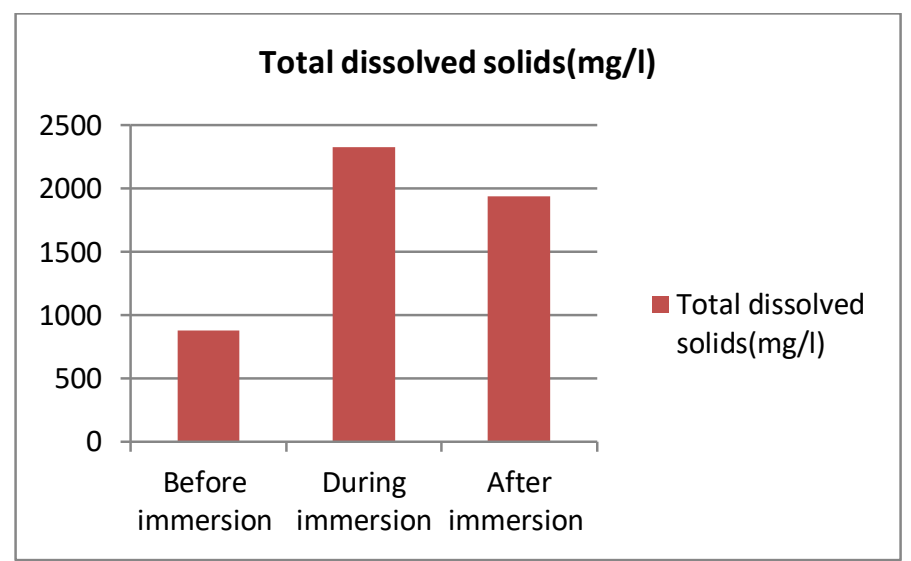

Figure 6 Comparisons of TDS 
International Journal of Engineering Applied Sciences and Technology, 2020

Vol. 4, Issue 10, ISSN No. 2455-2143, Pages 178-185

Published Online February 2020 in IJEAST (http://www.ijeast.com)

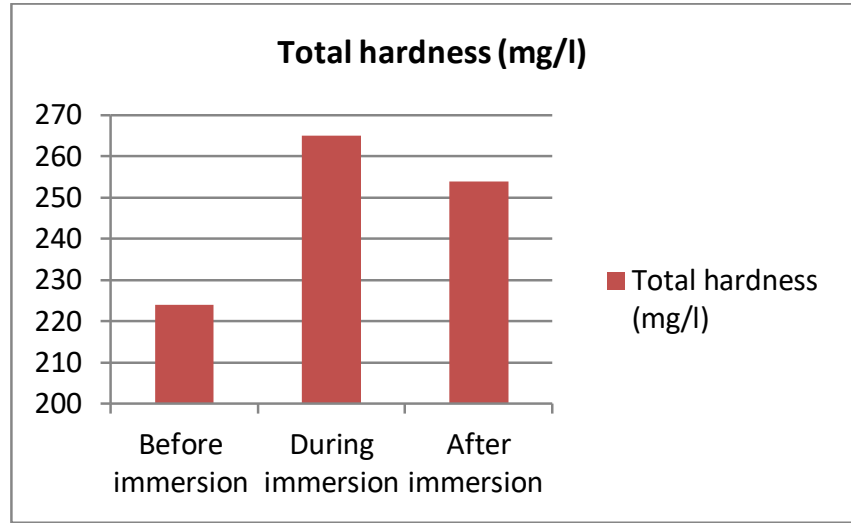

Figure 7 Comparison of Total Hardness

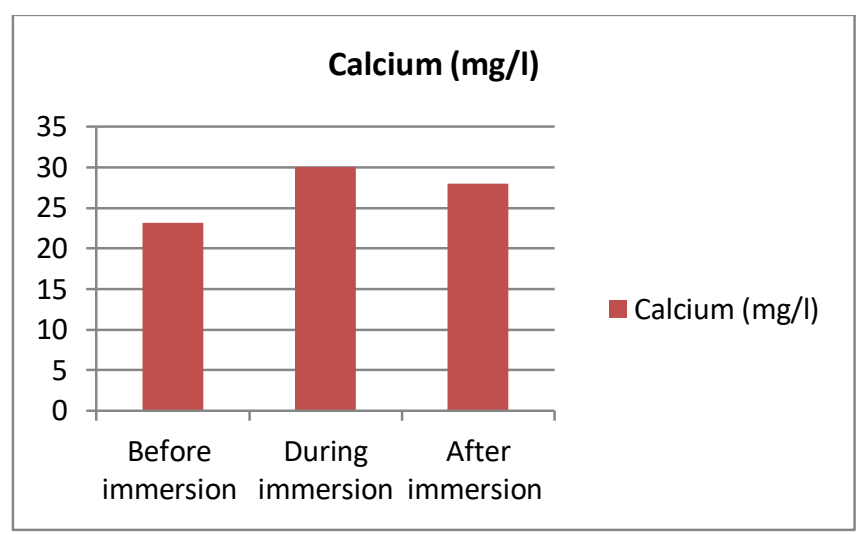

Figure 8 Comparison of Calcium

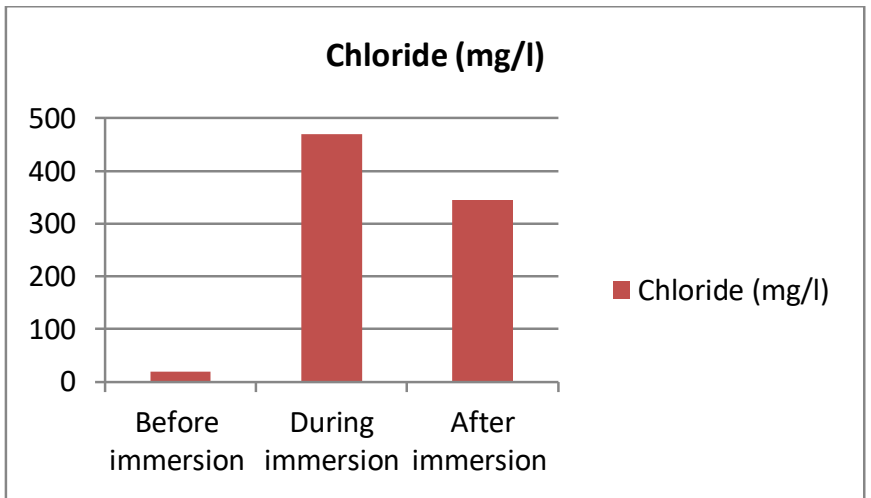

Figure 9 Comparison of Chloride 
International Journal of Engineering Applied Sciences and Technology, 2020

Vol. 4, Issue 10, ISSN No. 2455-2143, Pages 178-185

Published Online February 2020 in IJEAST (http://www.ijeast.com)

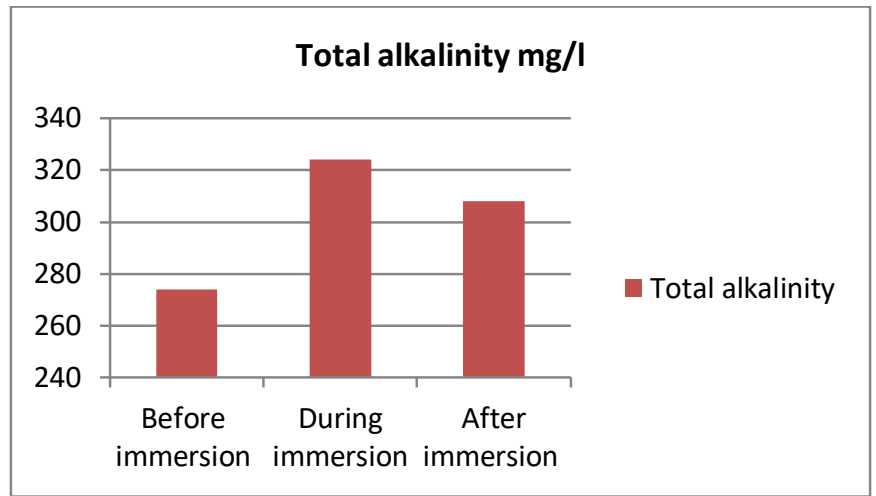

Figure 10 Comparison of Total alkalinity

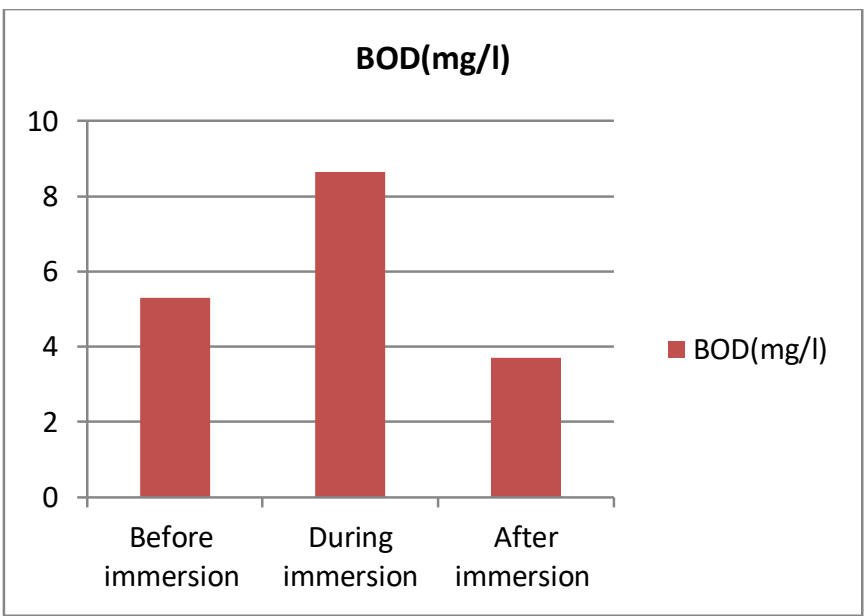

Figure 11 Comparison of BOD

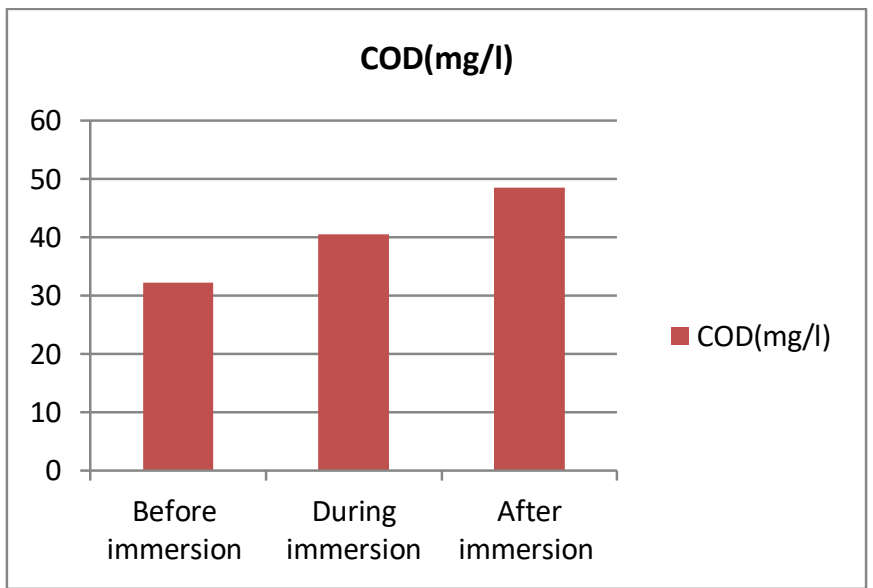

Figure 12 Comparisons of COD 
International Journal of Engineering Applied Sciences and Technology, 2020

Vol. 4, Issue 10, ISSN No. 2455-2143, Pages 178-185

Published Online February 2020 in IJEAST (http://www.ijeast.com)

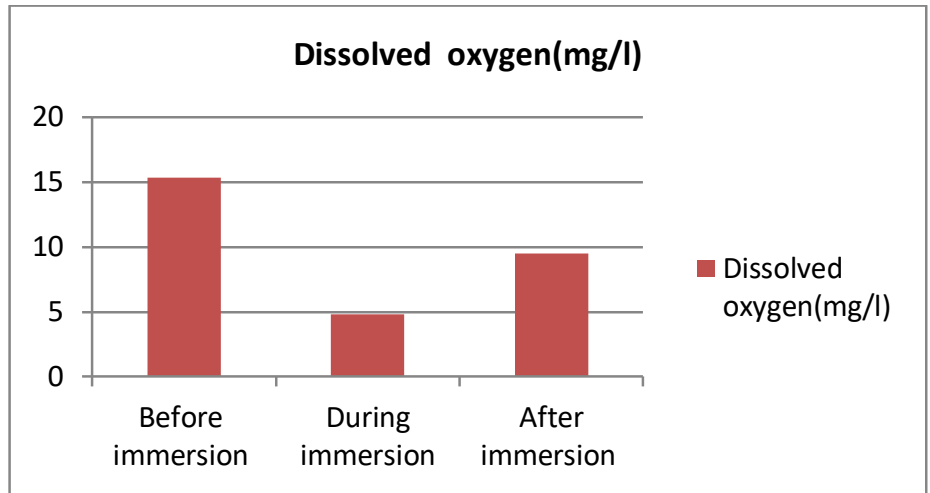

Figure 13 Comparison of DO

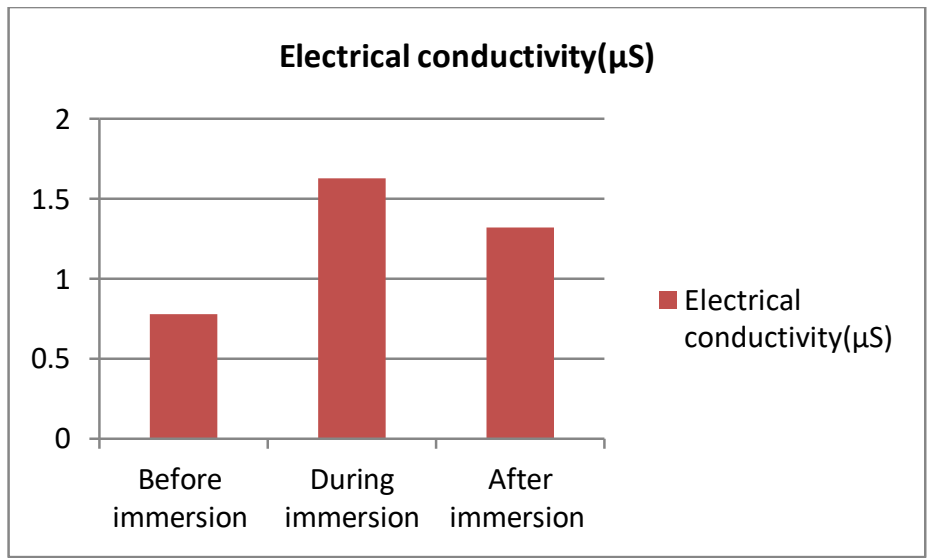

Figure 14 Comparison of EC

\section{CONCLUSION}

Impact of water pollution is seen during the festival season when immersion of idols in these natural aquatic ecosystems destroyed the whole ecological balance. The present study on assessment of idol immersion on Physico-chemical characteristics of water bodies in Jodhpur revealed that idol immersion activity has a negative impact on water quality of the pond. The water quality parameters like $\mathrm{pH}$, temperature, TDS, electrical conductivity, hardness, DO, BOD, and COD have shown significant increase during and after immersion of idols and then declined in the post immersion period. The input of biodegradable and non-biodegradable substances deteriorates the pond water quality. Problem of waste water becomes more severe when dissolution of input in the environment exceeds the decomposition, dispersal, or recycling capabilities. Toxics from anthropogenic inputs not only alter the natural freshwaters, but also have detrimental effects whose impact can be felt for a long time. All the parameters studied, it is well established that pollution and pollutant load is slowly increasing in these water bodies. As such Municipal Corporation should act at the earliest to preserve these water bodies and restore their originality otherwise they will become dead in few years from now.

\section{ACKNOWLEDGEMENT}

I acknowledge all authorities of Jai Narain Vyas University Jodhpur, Rajasthan(India) for the support and providing the necessary facility to complete this work. Also, I am grateful to my friends, colleagues and family for their constructive comments and suggestions.

\section{REFERENCES}

1) APHA, (1995).Standard Method for the Examination of Water and Wastewater American Public Health Association, 19th 
edition. American Water Works Association, Washington, DC.

2) Bajpai A, Pani S., Jain R.K. and Mishra S.M., (2003).Concentration of Heavy metal through idol immersion in a tropical lake. Ecology, Environment and Conservation 8(2), (pp.157-159).

3) Dhote S., Verghese B. and Mishra S.M., (2001).Impact assessment of Idol immersion on water quality of twin lakes of Bhopal.Indian Journal of Environmental Protection 21 ,(pp.998-1005).

4) Gupta A.K., Mishra K., Kumar P., Singh C. and Srivastava S., (2011).Impact assessment of religious activities on the water quality of prominent ponds at Varanasi (UP), India. Plant Archives 11(1), (pp. 297-300).

5) Khapekar R.R. and Nandkar P.B., (2009). Environmental impact of idol immersion on water bodies. The Botanique 13(1), (pp.6).

6) Mehta P., (2013).Physicochemical parameters and consequential impacts due to festival waste in Jodhpur. The Experiment 17(1), (pp. 1166-1176).

7) Mukerjee A., (2003). Religious Activities and Management of Water Bodies: Case study of idol immersion in the context of Urban lakes Management. International Water History Association (3), (pp.325).

8) Reddy M. and Kumar Vijay A., (2001). Impact of Ganesh Idol Immersion on some water quality parameter of Hussainsagar. Current Science 81, (pp. 1412).

9) Trivedy, P.K., and Goel, R.K., (1986).Chemical and Biological methods water pollution studies. Karad, India, Environmental publication.

10) Ujjain N.C. and Azhar A.M., (2011).Impact assessment of Ganesh Idol Immersion Activities on the Water Quality of Tapi River, Surat (Gujarat) India. Research Journal of Biology 1(1), (pp.11-15).

11) Upadhyay K., Mishra P. and Gupta A.K., (2010).Physicochemical Studies of two ponds at Varanasi and Bhadohi under biotic stress. Plant Archives 10(2), (pp.691-693).

12) Variya, (2010).Impact of Ganesh Idol Immersion on Tapi River at Umara Ovara. M.Sc. dissertation, Veer Narmad South Gujarat University, Surat.

13) Varsani,(2010).Impact of Ganesh Idol Immersion on Tapi River at Ashwani Kumar Ovara. M.Sc. dissertation, Veer Narmad South Gujarat University, Surat.
14) Vyas A., Mishra DD, Bajpai A, Dixit S. and Verma N., (2006).Impact of Idol Immersion Activity on Lakes of Bhopal, India. Asian Journal of Experimental Sciences 20(2), (pp.289-296).

15) Vyas A., Bajpai A and Varma N., (2008).Improvement in water quality after shifting of idol immersion site: A case study of Uppar Lake Bhopal India. Environment Monitoring and Assessment 145, (pp.437443). 